\title{
SUKARNO'S THOUGHT ON THE IMPORTANCE OF REINTEGRATION OF RELIGION AND SCIENCE IN PESANTREN EDUCATION IN INDONESIA
}

\author{
Syamsul Kurniawan \\ IAIN Pontianak - Indonesia | syamsulkurniawan001@gmail.com
}

\begin{abstract}
This paper examines Sukarno's thought on the importance of integrating religion and science within Pesantren education. He believes that there should be no separation and dichotomy between religious science and the so called general science as they complement each other. Sukarno's view on this matter was influenced by several things among them is his concern that Pesantren, as an Islamic educational institution, should be an avant garde in promoting the integration between those sciences. In addition, Sukarno also has concern about the condition of the Pesantren at the time; the early twentieth century that, in his opinion, tend to be old fashioned and focuses merely on religious education.
\end{abstract}

Keywords: Sukarno, integration of religion and science, education in Indonesia, Pesantren.

\section{Introduction}

In course of history, the relationship between religion and science refers to two trends: the dichotomy of religion and science and the integration of religion and science. The first trend is more popular in the West while the second trend, the unity of religion and science, is increasingly more popular in the Muslim world nowadays. In the West, religion and science are once regarded as separate and it was only in the later development, that there was awareness in integrating and uniting both of them. Interestingly, the opposite trend happened in the Islamic world as they tend to draw more line between religion and science; the two things that actually were used to be considered as a unity. 
Ontologically, Islam justifies the integrative relationship between religion and science. In Islam, both reading the Qur'an and "reading" the universe (through research) are equally important to attain the truth. These two types of truth are mutually supportive and not contradictory. Islam is a religion that deals not only with theological and ritual matters but also with science and the quality of human life and civilization. ${ }^{1}$

Historically, Muslims in the early era held this idea dearly. Early Muslim scientists and scholars believe that the teachings of religion have the framework of science and, therefore, there was no dichotomy between Islamic science (theology) and the general, or the so called secular, science (non-theology). At the era, people believed that Islam is a religion with perfect teachings and that the teachings are also comprehensive and universal, including science. ${ }^{2}$

Islamic civilization enjoys its glory in the history with the existence of famous Muslim scientists among them are Ibn Sina, a philosopher who also masters medical science, Ibn Haytham, a physicist, Abu Abbas al-Fadhl Hatim an-Nizari, an astronomer, Umar Ibn Ibrahim alKhayyami (known as Umar Khayyam) is the author of a mathematics book entitles al-Jabr, Muhammad al-Sharif al-Idrisi as a geologist. Unfortunately, these great figures are no longer popular among today's Muslims. ${ }^{3}$

1 Abu Darda, "Integration of Science and Religion: Conceptual Development in Indonesia", in At-Ta'dib, Volume 10, Number 1 (June 2015), p. 35.

2 Nasruddin Razaq, Dienul Islam (Bandung: Almaarif, 1996), p. 7. Jasa Ungguh Muliawan, Pendidikan Islam Integratif (Yogyakarta: Pustaka Pelajar, 2005), p. 1.

${ }^{3}$ In the $7^{\text {th }}-13^{\text {th }}$ century CE the Islamic world enjoyed a golden era, with a rapid development in the field of science and technology. There are at least several factors that led to the rapid advancement of science in this period: first, Islam became the motivation; secondly, the unity of language that facilitated scientific communication (i.e. Arabic); third, the existence of government policies in the development of science; fourth, the establishment of academies, laboratories, and libraries as a means of development of science; fifth, persistence of scientists to conduct research and experiment; sixth, an international view opening up isolation with the outside world; seventh, mastery over the former Greek classical philosophical development area. In this period, the Islamic world developed a science derived from the Qur'an and Hadith, as well as science that comes from nature and society, but was still in the "one roof" of Islamic knowledge. In was in the $13^{\text {th }}$ century when the development of science among Muslims revealed a setback phenomenon. In contrast to the Western world, the legacy of science that had previously developed in Muslims, they learned and developed so as to be able to lead them into the era of renaissance. From now on there has been a tendency among Muslims to sort through which knowledge they may 
During the post-medieval era, there was a tendency to separate non-religious sciences group from the group of the religious sciences. ${ }^{4}$ This separation leads to the absence of understanding and integrating non-religious sciences to the religious sciences in which the basic foundation of religious science is Qur'an and Hadith. ${ }^{5}$ The idea of reintegrating religion and science among Muslims in second half of $20^{\text {th }}$ Century is stimulated by the concerns of some scientists and intellectuals who are against the declining understanding among Muslims towards Islamic education. ${ }^{6}$ Sukarno, for example, was one of the intellectual Muslims who has concern about the declined level of education among Indonesian Muslims, especially those in Pesantren.

It is important to note that, in the early twentieth century, Pesantren that was supposed to carry out the educational functions and reforms were actually became the centre of "anti-Dutch sentiment". 7 This antiDutch attitude was the standpoint of the Pesantren at the time since they view Dutch as bringing serious religious and cultural threats. Consequently, the Pesantren was suspicious of anything that comes from the West (read: the Netherlands) and this, unfortunately, includes

learn and which they should not. Science taken directly from the Qur an and Hadith can be studied and viewed as the structure of Islamic science, while the science that comes from nature and from society should be removed from the structure of science in Islam. This situation is the background of the dichotomy between religion and history of Islam that led to the decline of Muslims up to now in many aspects, especially in Islamic educational institutions. Endang Saifuddin Anshari, Wawasan Islam: Pokok-Pokok Pikiran tentang Islam dan Umatnya (Jakarta: Rajawali Press, 1991), pp. 120-125; Syamsul Kurniawan, "Dikotomi Agama dan Ilmu dalam Sejarah Umat Islam, Serta Kemungkinan Pengintegrasiannya," Fikrah, Volume 1, Nomor 1 (2013), pp. 140142.

${ }^{4}$ Azyumardi Azra, "Rekonstruksi Kritis Ilmu dan Pendidikan Islam", Abdul Munir Mulkhan, et. al., Religiusitas Iptek. (Yogyakarta: Fakultas Tarbiyah IAIN Sunan Kalijaga Yogyakarta and Pustaka Pelajar, 1998), pp. 78-83.

5 M. Amin Abdullah, et al., Islamic Studies dalam Paradigma Integratif-Interkonektif (Yogyakarta: Suka-Press, 2007), p. 27.

${ }^{6}$ Read for example, a signal about the acute crisis that is engulfing inner Islamic education, Abdul Hamid Abu Sulaiman (ed.), Islamization of Knowledge General Principles and Work Plan (Virginia, USA: IIIT, 1989), p. 5.

7 Ahmad Mansur Suryanegara, Menemukan Sejarab: Wacana Pergerakan Islam di Indonesia (Bandung: Mizan, 1998), p. 240. 
Western science; science from the western world. ${ }^{8}$ In this sense, it is save to say the Pesantren at the time was closer to conservatism. ${ }^{9}$

This attitude is understandable as Islamic educational institutions especially Pesantren, in accordance to the mission of colonialist mission, were marginalised. The Dutch colonial government considered Pesantren as an illegal school. In relation to this, they issued a regulation known as the Wilde Schoolen Ordonantie in 1933 which is a legal instruction ordering the closing of private schools, including Pesantren. ${ }^{10}$ Before this, the colonial government had also issued a regulation known as the "Teacher Ordinance" (Ordinance 1905 and 1925) in which the teacher should have a written permission in order to teach Islamic teaching. Here, he or she also has to include the subject lists, the name of the students participating in the class, and the methods used in the teaching. ${ }^{11}$

The ordinance was explicitly intended to restrict the movement of religious teachers and to impede the progress of Islam.12 The colonial government, through its policies, limited the role of Islam in the public sphere. As a result, Pesantren faced difficulties in its public activities and was also marginalized from the ongoing development. ${ }^{13}$

At the same time, Pesantren suspected the Dutch. Their standpoint resulted in, at least, two significant consequences. One consequence is the growing 'heroic' spirit among Muslims and Pesantren community and this spirit targets The Dutch as enemy for Muslims. Another consequence, as Pesantren was being marginalized from public sphere and social life, there encouraged the participation of new interactions in the community. It makes clear dichotomy in Pesantren education in which people view religion and science as something separate. ${ }^{14}$

In regards to this view, Sukarno believes differently and argues that Islamic sciences are not limited to theology, that is science of the

\footnotetext{
${ }^{8}$ Karel A. Steenbrink, Pesantren, Madrasah, dan Sekolah (Jakarta: LP3ES, 1992), p. 43.

${ }_{9}^{9}$ Mahmud Arif, Pendidikan Islam Transformatif (Yogyakarta: LKiS, 2008), pp. 178-179.

${ }^{10}$ HAR. Tilaar, Paradigma Baru Pendidikan Nasional (Jakarta: Rineka Cipta, 2000), p. 169.

${ }^{11}$ MB. Hooker, Islam Mą̧hab Indonesia: Fatwa-Fatwa dan Perubahan Sosial (Jakarta: Teraju, 2003), p. 36.

12 Alwi Shihab, Membendung Arus; Respons Gerakan Mubammadiyah terbadap Penetrasi Misi Kristen di Indonesia (Bandung: Mizan, 1998), p. 149.

13 Tilaar, Paradigma Baru, pp. 169-170.

14 Syamsul Kurniawan, Gagasan Pendidikan Kebangsaan Soekarno: Ide Progresif Atas Pendidikan Islam Indonesia (Malang: Madani, 2016), p. 3
} 
Qur'an and the hadith but also are other subjects including here the so called general science such as math and chemistry. This view is based on a belief that Muslims could and should become modern by mastering both sciences. ${ }^{15}$ Sukarno's thought on Islamic education was influenced by his educational background. He actually never experienced specific Islamic teaching like those who go to Pesantren or madrasah for their education. On the contrary, he actually received Western-style education from the Dutch. Sukarno thought that western education helped the development of modern Islamic schools in Indonesia. Sukarno himself believed that he became more appreciative about Islam after reading modern and scientific Islamic books. ${ }^{16}$ Some studies found the following descriptions:

One of the explanation is offered by Taufik Adi Susilo who wrote a book titled 'Soekarno: Brief Biography 1901-1970'. ${ }^{17}$ The purpose of this book is to bring back the figure of Sukarno and his thoughts including his positive and provocative statements. This book describes how Sukarno, as the founding father of the nation, experienced bitter realities and painful political rivalries and ended up sadly. After being ousted from presidency, he was dumped, oppressed, marginalised and even cast away by the New Order Regime until his death in 1970.

Another writer is Benhard Dahm. He wrote the story of Sukarno entitled 'Sukarno and the Struggle for Indonesian Independence'.18 Dahm explores Sukarno's background comprehensively and positioned him as a great thinker equipped with talents and skills and also as a leader. He also shows how his leadership skill has brought him to the top of the pyramid of Indonesia's power and became the first President of Indonesia. Furthermore, Sukarno also is portrayed here as having syncretic thought between nationalism, Islam, socialism and Javanese traditionalism, and this very view is what made him a charismatic leader.

Susilo and Dahm's books focus on Sukarno's political thoughts and struggles. Nevertheless, the books do not explore Sukarno's Islamic beliefs. Here is where Cindy Adams fill the gap and discussed

\footnotetext{
15 Sukarno, Dibawah Bendera Revolusi, Vol. 1 (Jakarta: Panitya Penerbit Dibawah Bendera Revolusi, 1965), pp. 334-336.

16 Ibid., p. 337.

17 Taufik Adi Susilo, Soekarno: Biografi Singkat 1901-1970 (Yogyakarta: Garasi, 2008).

18 The book of Benhard Dahm is translated by Hasan Basri entitled Soekarno dan Perjuangan Kemerdekaan (Jakarta: LP3ES, 1987).
} 
Sukarno's religion and his Islamic views in her book entitled Bung Karno Penyambung Lidah Rakyat Indonesia (Bung Karno, the Communicator of Indonesian People's Voice). ${ }^{19}$ This book reveals Sukarno's background, personality, and struggle. The book also reveals that Sukarno's parents influenced his religious thoughts. Sukarno's father was a Javanese priyayi who formally claimed to be an adherent of Islam, more specifically a follower of Javanese mysticism. His mother had Balinese royal family background of Brahmin and Hindu descent. The book also describes how both his father and mother contribute to shape his religious thoughts and gave him religious advice in accordance to their religious teachings.

Sukarno's ideology is often considered as "human synthesis." This is due to the fact that he personifies the three ideological schools that flourish in Indonesia; they are nationalism, Islam and communism. Clifford Geertz in his book 'Islam I'm Observing: Developments in Morocco and Indonesia' refers to Sukarno as a personification that represents the religiosity of the Indonesian nation. ${ }^{20}$

Bambang Noorsena's book entitles 'Religi dan Religiusitas Bung Karno: Keberagamaan Mengokobkan Keindonesiaan"1 highlighted the religious views of Sukarno critically. According to him, Sukarno was a controversial figure. "What is Sukarno's theological view? This is question that Noorsena wants to answer or explain in his book. As Noorsena writes in his book, Sukarno called himself as a PantheistMonotheist. He said that he believed that God is one, but he felt that His presence is everywhere. Interestingly, Sukarno's word once expresses that God is also "in the smile of a girl". Sukarno borrowed the argument from Bhagavad Gita. What made Sukarno even more controversial is the fact that he once confessed to Louis Fisher that he was at once a Muslim, Christian and Hindu. Noorsena's reviews can be used as an additional reference, particularly for projecting the extent of Sukarno's thought.

Maslahul Falah in his book 'Islam ala Soekarno: Jejak Langkah Pemikiran Islam Liberal Indonesia' (Islam ala Soekamo: Trace of Liberal

${ }^{19}$ Cindy Adams, Bung Karno Penyambung Lidab Rakyat Indonesia (Jakarta: Gunung Agung, 1982).

${ }^{20}$ Clifford Geertz, Islam yang Saya Amati: Perkembangan di Maroko dan Indonesia (Jakarta: YIIS, 1982).

21 Bambang Noorsena, Religi dan Religiusitas Bung Karno: Keberagamaan Mengokobkan Keindonesiaan (Bali: Djagadita Press, 2001). 
Indonesian Islamic Thought)22 explores history of how Sukarno begun for searching his thoughts in Islam. The use of turbulence of Islamic thought in Indonesia as the background discussion of the book needs to be reconsidered. Falah discusses only general perception without considering the educational aspect. Although Falah solidly leads to the form of Sukarno's Islamic thought, there are limited statements that discuss this issue.

There is also another book entitled 100 Tabun Bung Karno ${ }^{23}$ edited by Joesoef Isak. This book is a collection of works by many writers. This book actually is intended to be an appreciation towards Sukarno and to commemorate the 100th anniversary of his birth. Among the contributors of this book are Chairil Anwar, Dawam Rahardjo, Pramoedya Ananta Toer, Ben Anderson, Joop Merrien, Harry Poeze, Noam Chomsky, and others. Each of them highlights and analyses Sukarno based on their perspective and understanding.

Another book worth mentioning is the one by Badri Yatim, Soekarno, Islam dan Nasionalisme. ${ }^{24}$ In the book, Badri discusses about the biography of Sukarno and his thoughts, especially on nationalism and Islam. Through his writing, Yatim wants to explore the Sukarno's life story which includes the background of the family life, religion, and politics. Yatim also examines the essence of Sukarno's thought on Islam and nationalism, as well as his polemic with M. Natsir and A. Hassan, two Indonesian modernist Muslim thinkers.

Deliar Noer in his book 'Gerakan Modern Islam di Indonesia 1900$1942^{25}$ also discusses Sukarno's Islamic thought, specifically in the area of politics and nationalism. Noer puts the discussion on this issue in a chapter on secular group reactions. Unfortunately, he does not profoundly review and analyse Sukarno's thoughts.

In addition to the works mentioned above, there are many other works offer discussion about Sukarno, his thoughts and career. However, there are very few studies specifically discus Sukarno's concept on the importance of integrating religion and science within Islamic education, particularly in Pesantren. This paper is intended to fill

\footnotetext{
22 Maslahul Falah, Islam ala Soekarno: Jejak Langkah Pemikiran Islam Liberal (Yogyakarta: Kreasi Wacana, 2003).

23 Joesoef Isak (ed.), 100 Tahun Bung Karno (Jakarta: Hasta Mitra, 2001).

${ }^{24}$ Badri Yatim, Soekarno, Islam dan Nasionalisme (Jakarta: Logos Wacana Ilmu, 1998).

${ }^{25}$ Deliar Noer, Gerakan Modern Islam Indonesia 1900-1942 (Jakarta: LP3ES, 1996).
} 
in the gap and aims to focus on this aspect. This study on Sukarno's thought on Islamic education is a literature study that requires more philosophical and theoretical processing instead of empirical testing in the field. ${ }^{26}$ The data was from the documents from both primary and secondary sources. The records were then analysed and understood to answer the objective of the study.

\section{Sukarno as a Modernist Muslim}

Sukarno was born on June 6, 1901, and died on June 21, 1970. He was a prominent figure of Indonesia and was recorded in the history of Indonesia as the first President of the Republic of Indonesia. Together with Mohammad Hatta, Sukarno announced the Proclamation of Indonesian Independence on August 17, 1945. Therefore, he got the title as the father of the Proclamation. He is also known as the founding father who played an essential role in generating, giving national identity and laying the foundation of the country, that is Pancasila which he delivered on June 1, 1945.27

Sukarno was the follower of Javanese Sufism teaching. His mother was a Hindu Balinese. He received secular Western education during the Dutch colonialism. He was active in political activities from a young age, reaching his peak as a proclaimer of Indonesia's independence and as the first President of the Republic of Indonesia.

In addition to reading many books related to the politics and ideology written by Western scholars (especially the socialist ones), his thinking was influenced by Islamic scholars, both the local and international scholars. He was an active member of Islamic group (e.g. Muhammadiyah) and also known as the founder of the Indonesian National Party (PNI).

Sukarno was very interested in understanding and learning Islamic teaching, especially during his times in prison (Sukamiskin). When he was exiled in Ende, He has a lot of time to learn and express his thoughts about Islamic education. He began to express his views on Islam in mass media, primarily when he was in Bengkulu. ${ }^{28}$

Sukarno shows tendency to become closer to the Islamic modernist group, particularly in the way he expresses his opinion

\footnotetext{
${ }^{26}$ Noeng Muhadjir, Metodologi Penelitian Kualitatif (Yogyakarta: Rake Sarasin, 1996), p. 159.

${ }^{27}$ Susilo, Soekarno: Biografi, p. 13.

28 Yatim, Soekarno, Islam, p. 1-2.
} 
which is influenced by the level of education and knowledge he gained. As mentioned previously, He received western education during the Dutch colonialism. On the positive side, western education has indeed contributed to the development of modern Islamic schools in Indonesia. However, Western education also contributes to the fostering of hatred for various forms of 'worship' of magical goods and Sufi or mysticism. ${ }^{29}$

Sukarno himself wrote:

Most Muslims do not want to catch up with the times and it is because of the wrong people who propagate Islam: they are oldfashioned, they are orthodox, they are anti-knowledge and are not knowledgeable, superstitious, telling people to just simply 'believe'. It's nasty!..30

Through the collection of Bukhari and Muslim's books, Sukarno read and studied the content of hadith. Not only he understands the books, he also criticised the hadith. In his time, the criticism towards hadith was a very rare move. Only a few, usually are the modernists who are open to this attitude. Sukarno's thought and criticism towards hadith is in line with the Islamic organisation he followed, Muhammadiyah as they acknowledge the importance of modernisation of Islam. ${ }^{31}$

Sukarno, who has dream of modernising Islam, often looks at things differently and offers fresh thought that is more advanced than the leading Muslim thinkers at that time. For example, he suggested the use of historical materialism methods taught by Marx in studying religious beliefs. His multifaceted concerns about Islam ranges from social, political, educational, scientific, and other aspects. He then advocated the use of modern science such as social sciences, biology, and astronomy in attempts to study and understand the Qur'an. ${ }^{-}{ }^{32}$

\footnotetext{
${ }^{29}$ HAR. Gibb, Aliran-Aliran Modern dalam Islam (Jakarta: Tinta Mas, 1954), p. 46.

30 Sukarno, Dibawah Bendera, p. 337.

${ }^{31}$ As one of the great Islamic organizations, which emphasizes its charitable efforts on social welfare, Muhammadiyah was then considered a representation of the modernist school of thought. Achmad Jainuri, Ideologi Kaum Reformis: Melacak Pandangan Keagamaan Mubammadiyah Periode Awal (Surabaya: LPAM, 2002), p. 4.

32 Isak (ed.), 100 Tahun, pp. 139-140.
} 
Sukarno expressed his ideas and interest in the modernisation of Islam's 'understanding' and 'propagation' to A. Hassan as described in the following statement:

Some Qur-anic interpretations of classical period such as Tafsir alBaghawi, Tafsir al-Baidhawi, and Tafsir al-Khazin contain weaknesses. The defects are, for example, how people can understand the words of God that are made by him 'in pairs' if they do not know biology, do not know the electrons, do not know positive and negative and do not know action and reaction. How can people understand His words that 'you see and imagine the mountains are hard when they all run as the clouds,' and that 'the sky was originally like a united substance, and we broke and made it everything that comes from water'- if you do not know a little astronomy? How do you understand the verses that narrate Alexander if you do not know a bit of history and archaeology? Look at that blunder of Islam as 'Sultan Iskandar' or 'the King of Pharaoh' or 'the war of blood that brings death to thousands of people until people swim in the sea of blood! It's all because of lack of historical research and natural science..$^{33}$

Sukarno's approach, employing science in the efforts to study and understand Islam, was later followed by many Muslim thinkers. It proved that Sukarno's thought about Islam is profound and often precedes his time. Another example of his excellent thought is his views on women status in Islam. He undeniably had a feminist standpoint and offered feminism ideas. He talked about gender issues, long before modern Muslim thinkers raised the notion and discourse as it shown in one of his book entitled Sarinah. ${ }^{34}$

In this book, Sukarno dissected the root causes of women's discrimination from social, economic and religious standpoint. He believed that the evolution of religious views follows the stages of the development of society. It is in line with the theory of August Comte which states that the development of society is on the scene of production (in Marxist terms: modern mode of production and social formation) and the religion embraced by the community. In the beginning, people worshipped the spirit that existed in the objects and the minds of the ancestors (animism and dynamism), then they made

\footnotetext{
33 Sukarno, Dibawah Bendera, p. 336.

${ }^{34}$ Sukarno, Sarinab (Jakarta: Panitya Penerbit Karangan Presiden Sukarno, 1963).
} 
idols and worshipped them. In the era of agrarian society, they believe in God. ${ }^{35}$

It is important to note that, long before Sukarno studies Islam, he had a different view towards some of Islamic teachings. Therefore, Sukarno's concept of Islam did not always correspond to the opinions of most Muslims in his day. Regarding Indonesian women for example, Sukarno expected women to advance in various fields; view that is very new at the time. He argued that Islam never prevents women from engaging in activities like men. He described this in his speech in the PNI (Partai Nasional Indonesia/Indonesian National arty) Congress in August 1929, which carried the theme "The Movement of Indonesian Women" as follow:.

My brothers and sisters. I am here to talk about the movement of women in Indonesia as I wish Indonesia independent. The evolution of women has begun everywhere in the country and all over the world. This movement in Indonesia compared to the action in other places is still left behind. There are some who say that Islam is an obstacle. It's not at all. Islam is the one that upholds the dignity of women to a highest degree.

In the land of Islam, there are prominent and famous women, for example, Fatimah who thought of essential matters, Zabeida the consort of Harun al-Rashid who had her women in the waterway in Mecca and established the City of Alexandria, and Fakhroennisa Sheika Sulda who spoke about literature and poetry in Baghdad. Indonesia's women are like Naidu in India. Does Indonesia have a woman like Sung Soong Chung in China? These thumbs-up women from Asia is a model for women in Indonesia. ${ }^{36}$

The development of Sukarno's ideas on Islam is similar to Shari'ati's thought which was influenced by Marxism. His tendency toward Marxism shows that Sukarno was a forward-thinking, open, and scientific man as he said:

“... it is true that there have been 'youth' associations here. It is true that there already exists Muhammadiyah or Persis (Persatuan Islam/Islamic Unity) or other 'youth' associations, but it has not

\footnotetext{
35 Isak (ed.), 100 Tabun, pp. 49-61 and p. 144.

36 Pitut Soeharto and A. Zainoel Ihsan, Aku Pemuda Kemarin di Hari Esok: Kapita Selekta Kumpulan Tulisan Asli, Lezing Pidato Tokoh Pergerakan Kebangsaan 1913-1938 (Jakarta: Jaya Sakti, 1981), p. 197.
} 
been any voice of rationalism. Both Muhammadiyah and the action of Islamic unity said that 'the youth' is the pillar of the religious investigation but this concept is still an old pillar. ${ }^{37}$

What he thought was the reason why the Muslim intellectuals were alien to their religion, Islam. The scholars will return to the Islamic environment when they have the freedom to interpret Islam. Otherwise, Sukarno said, "they are not capable of catching fire; we have a religion, but it is only able to grasp the ashes". he further said:

So, therefore, Muslim leaders, let us break the memory of the thought tradition that has been there for almost a thousand years. Let's not just celebrate Islam in its branches, but let us join it into the primary roots of the tree. ${ }^{38}$

In the study of Islam, Sukarno argued that reason is an important position. According to him, any problems, including religious issues,

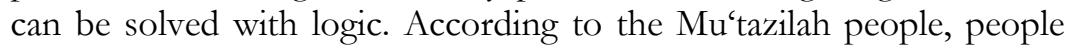
should interpret the verses of the Quran according to the reason. When there are verses that contradict the mind, they should explain the verses in harmony with reasons.

The mind sometimes does not want to accept the Qur an and the authentic Hadith, not because the Qur'an and the Prophet are wrong, but because the way we interpret is wrong. If there is any sentence in the Quráan or the Prophet's words are contrary to the reason, then rationalism search for the interpretation of adequate information. ${ }^{39}$

As a supporter of the Islamic reform movement, Sukarno continued to demand the reform in the notions of Islam. Sukarno elaborated:

I want to talk about how Islam speaks about "youth". I want to talk about "regeneration" in general. We now need to rethink about what we understand about Islam, re-examine whether it is true that all of us have an understanding of Islam and whether there are no notions that need to be corrected. Let us not stand stubbornly as what the Shaykh of Trans Jordan said when asked whether there is a change of understanding in religion. He replied

\footnotetext{
${ }^{37}$ Sukarno, Dibawah Bendera, p. 398.

38 Ibid., p. 402.

${ }^{39}$ Ibid., p. 398.
} 
fiercely, "We do not need to talk about religion. In religion, there is no change". 40

\section{Sukarno continued:}

The time does not show evidence that there is always a change in the notion of religion! The time does not indicate that the old idea can be replaced by more recent sense-that is the correct notion corrects wrong understanding. For example, the correction of talqīn, usalli, taqlid, tauhid, bijāb, loan interest, women's understanding, and interpretation of the Qur an.

Panta rei, Heraclitus said that everything flows, everything changes constantly, and everything gets renewed. In the sense of the religious teachings of the panta rei, there is always a change. The subject does not change, religion does not change, the truth does not change, the word of God and the sunnah of the Prophet does not change, but the human understanding can change. Correction of the notion is always there and must be there. The correction is essential to all ijtibad; the correction is necessary to all investigations that lead us to the field of advancement. ${ }^{41}$

Sukarno invited Muslims to immediately adapt their life to the Islamic spirit, which he thought was only possible by continuously renewing and rejuvenating Islamic understanding through rationalism. According to him, through rationalism, there will be a harmony between the brain and the heart or between reason and belief. With rationalism, the leader could understand Islam; then there will be a real harmony between the mind and soul; reason and faith. Rationalism can change completely the way we view something. Islam indeed becomes a shelter, a way out, not a prison. With this understanding of Islam, as the sun rises, there will be a repair; reconnection between the intellectuals and Islam. He further asserts:

Because true Islam is not a young Islam on its skin deep, but make it young in every aspect! It is young body and soul!.42

\footnotetext{
40 Ibid., p. 370.

${ }^{41}$ Ibid.

42 Ibid., p. 402.
} 


\section{Sukarno's thought on the Reintegration of Religion and Science In Pesantren Education}

To date, the debate surrounding the dichotomy between religion and general sciences still occurs. Therefore, the concept of science integration remains an actual discourse. Some scholars view that religion and general science have two different categories: they have different study areas and orientation. Others say the opposite and argue that both religious and general sciences are two integrative components and mechanisms, and hence both should not be separated as they can complement each other that will potentially bring the benefit for humankind.

Concerning the concept and importance of the reintegration of science and religion, Sukarno had already discussed it. To him, every science has the same function. Despite the different areas of its work, all sciences are useful depending on how society treats science. Sukarno believed that the progress of Islam could only be achieved if Muslims can break away from dichotomous restraints and put all sciences in a balanced and proportional portion. In this case, Sukarno referred to general sciences of western science. Sukarno criticised that the traditional pesantren education model in the early 20th century was an ancient one and was inconsistent with the spirit of the times because it was only fixated on the teaching system that separated the religious aspects to the general aspects of science.

Sukarno said:

I know you have a pesantren, not a university, but it would be nice if there are a lot of western sciences. For the sake of Allah, Islamic science is not just the knowledge of the Qur'an and hadith alone; Islamic science is the knowledge of the Qur an and hadith plus general science! One cannot fully understand the Qur'an and hadith without general science. ${ }^{43}$

The implementation of the traditional educational patterns and avoidance of modern education make the shifting in the construction of religious thought and organisation in pesantren in four different ways. Firstly, Islam becomes a religion that deals with the problem of setting the direct relationship between servants and God, and the relationship between humans and others. Secondly, the deterioration of Muslims in the stage of history is because of abandonment of scientific endeavour

${ }^{43}$ Ibid., p. 336. 
by Muslims. Thirdly, the dominance of the rigid and black-and-white perspective has dominated Muslim thought. And the last is the indoctrinated pattern of teaching and emasculating criticism. Below are fundamental differences between the model of traditional Islamic education and the model of modern Islamic education:

Table 1: Fundamental Differences of Traditional Islamic Education Patterns and Modern Islamic Education Patterns ${ }^{44}$

\begin{tabular}{|c|c|}
\hline Traditional Islamic Education & Modern Islamic Education \\
\hline $\begin{array}{l}\text { Orientation towards the } \\
\text { hereafter: orientation towards } \\
\text { the past }\end{array}$ & $\begin{array}{l}\text { Modern orientation: orientation towards } \\
\text { the future }\end{array}$ \\
\hline $\begin{array}{l}\text { The purpose is for socialization } \\
\text { of Islam }\end{array}$ & $\begin{array}{l}\text { The purpose is for the development of } \\
\text { individuality }\end{array}$ \\
\hline $\begin{array}{l}\text { The curriculum has not changed } \\
\text { since medieval times }\end{array}$ & The curriculum follows subject changes \\
\hline $\begin{array}{l}\text { Knowledge is revealed and } \\
\text { cannot be altered }\end{array}$ & $\begin{array}{l}\text { Knowledge is gained through empirical } \\
\text { and deductive processes }\end{array}$ \\
\hline $\begin{array}{l}\text { The command of God increases } \\
\text { knowledge }\end{array}$ & Knowledge is used as a problem solver \\
\hline $\begin{array}{l}\text { Questioning perceptions and } \\
\text { assumptions are not justified }\end{array}$ & $\begin{array}{l}\text { Questioning perspectives and } \\
\text { assumptions are justified }\end{array}$ \\
\hline $\begin{array}{l}\text { Authoritarian learning - } \\
\text { indoctrinated }\end{array}$ & $\begin{array}{l}\text { How to learn involves student } \\
\text { participation }\end{array}$ \\
\hline Memorizing is very important & $\begin{array}{l}\text { Internalization of key concepts is very } \\
\text { important }\end{array}$ \\
\hline $\begin{array}{l}\text { Student mindset is passive } \\
\text { (always accept) }\end{array}$ & $\begin{array}{l}\text { Student mindset is active-positivistic } \\
\text { (critical) }\end{array}$ \\
\hline Education is not differentiated & Education can be highly specialized \\
\hline
\end{tabular}

Without intending to negate the existence of other determinant factors, it is reasonable to assume that the concept of static and functional degradation of traditional Islamic education-as confirmed by Hoodboy above has a close relationship with various absolutism. It

${ }^{44}$ Pervez Hoodbhoy, Ikbtiar Menegakkan Rasionalitas (Bandung: Mizan, 1996), p. 210. 
means that it is entirely untrue if there is an argument that Pesantren in the Sukarno era, both in the plain of concept and practice, was the media institutionalisation of absolutism. It is because Pesantren education has lost its transformative spirit due to too many "malpractice" in educational practices. At least, this can be seen from the pattern of traditional Pesantren education which separates the religious aspect and the general aspects of science in the teaching system.

In this case, Sukarno saw that with the help of general science, Islamic teachings could be understood in-depth and comprehensively. Rhetorically Sukarno questioned:

... How can one understand His word that "you see and think the mountains are hard objects when they all move as a cloud", and that "the ceiling is originally like a unified substance, then we broke it, and we made everything alive"-If not knowing a little astronomy? And, how do I understand the verses narrated by Iskandar Zulkarnain if I do not know a little history and archaeology? Look at the blunders of Islam such as Sultan Iskandar or "the Pharoah" or "the battle of Badar that brought the death of thousands of people into a sea of blood"! It's all because of the lack of historical investigation, less scientific feeling. ${ }^{45}$

Sukarno concluded that Islamic world would shine again, as it had in six centuries during the middle ages, if Muslims have passion for studying the phenomena of nature, and are willing to gain knowledge about things. Although at first glance it seems to have no correlation with the science of religion, it actually is very beneficial for a person to comprehend Islam deeply.

Sukarno said:

I have a sincere belief that Islam here-all over the world-will not be shining back if Muslims still have an ancient 'way of life', which rejects every 'westernisation' and 'modernisation'. Qur'an and hadith are the highest teachings, but they can then become the bearer of progress, a fire that burns if we read the Qur'an and hadith with general science. Yes, Qur'an and hadith oblige us to be the cakrawati in the field of all sciences and progress, in the area all sciences and advancement...46

\footnotetext{
45 Sukarno, Dibawah Bendera, p. 336.

46 Ibid., pp. 336-337.
} 
Sukarno viewed general science as the starting point for progress. At this level, he idealised the ideas of reform just like what Kemal Attaturk has fought for in Turkey or Riza Khan Pahlevi has brough in Iran. Also, Sukarno criticised those who could not accept modernisation and progress.

... Old-Fashionedness, ignorance and obscenity are the reason why many people cannot understand the validity of some new rules held by Kemal Attaturk or Riza Khan Pahlavi ...! The oldfashioned and nasty is - on the field of interpretation - why the whole western world views Islam as a religion that is anti-progress and astray. You can ask the European people who converted to Islam: in what way and from whom they got the idea of Islam. They would reply: not from teachers who only instruct their students to 'believe' and 'just believe', Not from the preachers who had a haunted look and only know tasbih, but from preachers who use a reasonable way of enlightenment - because they know general science... ${ }^{47}$

Discussions among contemporary Muslim thinkers have always mentioned that what Attaturk did in the past is wrong. Turkey adopted a non-selective Western culture since it was not the spirit of its advancement, not its science, not its work ethic, but only the outer shell of Western civilisation, a skin of no relevance whatsoever to the modernisation and progress of the West. Also, Turkey also imitates the West in terms of religious appreciation in the context of its relationship to socio-political problems. Thus, what happens is not "modernisation", but "secularisation" or even "westernisation".

Similarly, what is done by Pahlevi in Iran, was also no better than Turkey. The leadership of Pahlavi placed the interests of the United States above the interests of the Iranian people. It is no exaggeration to say that the Shah government was a puppet government that simply obeyed the will of America. The outbreak of the Islamic revolution in Iran in 1979, with the leadership of Ayatollah Khomeini, is the most typical picture of how the Iranian people themselves reject the ways of the Shah of Iran.

As Edward Mortimer argues, the Iranian Revolution is a picture of the people's spirit to restore Iran's Islamic identity and their rejection of all American interference, more widely, all Western culture. Thus, in my opinion, the idealised paradigm of Sukarno, which is oriented

${ }^{47}$ Ibid., p. 337. 
towards the example of Turkey and Iran, is not entirely the culture of Indonesia. Moreover, it is important to note that Indonesian people are known to be quite religious. Hence, I argue that taking the progressiveness of Western science does not mean that Islamic world, here Includes Indonesia, should imitate the patterns and styles of the West. So far, Islamic awakening is characterised as a re-enforcement of Islamic principles in everyday life. ${ }^{48}$

While Samuel P. Huntington has likened this model of Islamic revival to Protestant reform, the Calvinist Protestant is the basis of Protestant ethics which encourages people to save money. For Protestants, this view emerges because of salvation panic that one does not go to heaven. God will only give an opportunity to His brave, honest, and tenacious servant. The spirit of capitalism is an expression of religious doctrine that enables it to flourish in everyday life.

However, the analogy used by Huntington to put Islamic awakening in one line with Protestant reform, has a flaw. There is a difference between the two. The Protestant Reformation is firmly a lawsuit against religious doctrine, which is considered frozen and static. These reformers want the separated relationship between religion (church) and social issues. Meanwhile, in the case of Islam, the resurrection is marked by high enthusiasm for uniting religious and social-community areas. For them, these two areas are integrated.

In the glorious era of Islam (approximately around the medieval times), the separation of these two domains occurred within the community. In modern times, Islam suffered a setback because they abandoned religious doctrine and separated religion from $\mathrm{d}$ sociopolitical matters. In case of Europe, they experienced a decline when they clung to the teachings of religion. On the contrary, in Muslim world, the fall was due more to the abandonment of its religious teachings. This Islamic revival movement offers an alternative solution that is also Islamic as a 'third way'. This is called ;third way' as it differs from socialism and capitalism. John L. Esposito said that Islam is not merely a collection of teachings about faith and worship. Rather, Islam is actually a comprehensive set of ideology that covers all aspects of personal and community life. ${ }^{49}$

48 Edward Mortimer, Islam dan Kebebasan, trans. Ena Hadi (Bandung: Mizan, 1984), p. 280.

${ }^{49}$ John L. Esposito, Bahaya Hijau!: Kesalahpahaman Barat Terhadap Islam, trans. Sunarto (Yogyakarta: Pustaka Pelajar, 1997), p. 11. 
Based on the above description, Sukarno's rejection towards the science dichotomy (between religious and general science) as a way to advance Muslims can be accepted. Nevertheless, his tendency to idolize the reform figure of Attaturk and Reza Pahlevi in his offer to Muslim modernization in Indonesia is, in my opinion, needs to be reconsidered critically.

In spite of that, it is very interesting to see and explore Sukarno's approaches in trying to make Islam as part of the 'study area', as well as his emphasize on the necessity to employ other sciences as analytical tool for Islamic studies. Sukarno's views and thoughts, as mentioned previously, is quite advanced and ahead of time for his era. Sukarno said: "... Believe that if Islam is propagated in a reasonable and modern way, the whole world will be aware of the truth of Islam". ${ }^{50}$

This surely signifies the need for what is called the scientific method. The method of science opens up the opportunity for anyone to debate all the objects of study. Scientific methodological standards are essential so that the purpose of research is clear and can be considered as science. This is what Sukarno intended with "reason". In this context, the resulting science is neutral and depends on which party wants to test its validity. It may be true (the level of scholarly) is rejected or supported and reinforced by the data of others.

Thus, the most appropriate way to understand Islam is not merely to rely on "dogmatic" forces, which tend to do so through the process of "indoctrination", but through scientific methods that can be accounted for scientifically and logically. For the first way, it may be suitable for the lay people, but not for intellectuals and thinkers who need scientific arguments. These scientific arguments will open the veil of God's majesty so that it can open one's path to faith and Islam. In this case, Sukarno himself admitted that he was more respectful of Islam after he studied Islam through modern Islamic and scientific books.

In short, according to Sukarno, revelation and reason do not have to be dictated in Islam. This is because both can be used and complement each other. However, religious knowledge will be applicable and can bring the benefit for the society if religious knowledge is translated through the approach of modern social

${ }^{50}$ Sukarno, Dibawah Bendera, p. 337. 
sciences. Today, what Sukarno thinks has become a norm and has been recognised by most Muslims.

For Sukarno, there should be no dichotomy between religious science and general (secular) science in Pesantren education. Again, this is due to his believe that the two sciences essentially have the same orientation and can complement each other. Therefore, Individuals could study religion along with the general science during their education.

\section{Sukarno's Thoughts Reconsidered}

As a typical indigenous education institution of Indonesia, which has grown and developed since the presence of Islam in Indonesia, it is safe to say that Pesantren might be the embryo of a university in Indonesia. We can see similar trend in other parts of the world. Many prestigious universities in the West, such as Harvard, Oxford, and others that started as a form of theological school. What makes Indonesian case is different is the unfortunate fact that Pesantren, that actually can be the leading educational insititution nowadays, do not enjoy the same development like those in Western world. It has been pointed out that, during the colonial era, Pesantren which should carry out the functions of education became the centre of anti-Dutch sentiment. This anti-Dutch attitude is displayed by Pesantren, with the opposition attitude to anything that comes from the West, including in terms of science. It is the origin of the dichotomy of two sciences in Pesantren education.

The separation of religious science and general science in Pesantren during colonialism, such as the trend of Pesantren in the early of the twentieth century, as Sukarno criticised, will only make an incomplete paradigm of Islamic scholarship, so they must be combined. Therefore, its teaching material, dogma, and intuitive nature need to be derived and attributed to the earthly, empirical reality and experience. ${ }^{51}$

Here, I see that, For Sukarno and other scholars, the urgency to reintegrate religion and science into Islamic education is not only as a response to the backwardness of Muslims in science and knowledge but also due to the Muslim's recent response to the secular advancement of Western science. With the reintegration of religion

51 Sembodo Ardi Widodo, "Problematika Pendidikan Islam: Suatu Tinjauan dari Aspek Epistemologi", in Abdurrahman Assegaf, et al., Pendidikan Islam di Indonesia (Yogyakarta: Suka Press, 2007), pp. 39-40. 
and science, religion is expected to be more meaningful. On the other side, with the integration, general science will not lose the spiritual values. Thus, both can be blessings for the adherents, the humanity, and the universe. ${ }^{52}$

Until the late 20th century, most Muslim-majority nations, especially the developing countries, experienced similar common problems: population boom and poverty. People from the developing countries are aware of their backwardness compared to the developed countries especially in the field of science and technology. To give illustration, it can be said that Islamic world lacks the mastery of science and technology let alone creates it. ${ }^{53}$

Until the end of the twentieth century, people at developing nations still prioritise the theological and ritual aspects and consequently rule out the scientific knowledge. As a result, Islamic education system is still preoccupied by religious matters and leaving behind the elements of science and technology.

According to Ismail Raji al-Faruqi, the solution to this problem is to Islamize science while avoiding the pitfalls and lack of traditional methodology. The Islamization of science must observe principles which are the essence of Islam. This is in line with Jalaluddin and Usman Said's view that to reinstate disciplines under Islamic framework means to make theories, methods, principles and objectives to submit to: the unity of God, the integration of the universe, the unity of knowledge and truth, the unity of life, and the unity of mankind. Based on this view, Islamization of science in education; here includes the integration of both educational systems between modern Islamic and Western education is through the filtering of science into a necessity. Islamic culture should be integrated into the education model with the secular system of public schools.

Similarly, as Sukarno wanted the Pesantren to be, Ismail Raji alFaruqi offered the Islamisation of science in Islamic education. His idea is by merging two educational systems; traditional and modern, into a current Islamic educational system. This way is intended to eliminate the problem of dichotomy between the two sciences; religion and general, within the education system that occurs among the people. The idea of "Islamisation of Science" in Islamic education

\footnotetext{
${ }^{52}$ Kurniawan, Dikotomi Agama, pp. 146-147.

${ }^{53}$ Nurchalish Madjid, Kaki Langit Peradaban Islam (Jakarta: Paramadina, 1997), p. 21.
} 
holds a principle stating that, even though it is true that Western science should not be rejected and is necessary to be accepted, it must go through a process of filtering that is carried out within the Islamic framework. This consequently means that they can not contradict the message of the Qur'an and al-Hadith.

Ismail Raji al-Faruqi stated that various subjects in western science such as the humanity, social science, and other Western science must be re-examined and nurtured. The strategy then, according to him, is to give the basis of Islam and given new goals in line with Islam in the methods, strategies, data, problems, objectives, and aspiration. It needs to be rearranged to conform with Islam with a faction that forms tawhìid. ${ }^{54}$

According to Azyumardi Azra, there are three typologies of science integration, they are: restorationism, reconstructionism, and reintegration. However, reconstructionism and re-integration are the most common ways found in Islamic educational institutions, including Pesantren. Reconstructionism has been the debate for a century and ends with the Islamization of science..$^{55}$

Kuntowijoyo stated that the essence of integration is the effort to unite (not merely combine) God's revelation and the discovery of the human mind (integrated sciences) without excluding God (secularism) or eliminating men (Islamization of science). ${ }^{56}$ In this context, Kuntowijoyo assumes the need to formulate the theory of science based on the Qur an and make Quran the paradigm. The efforts made are objectification so that Islamic teachings contained in the Qur an can be actualized to bring benefits to the universe (rabmatan li al 'alamin ${ }^{57}$

The essence of integration is to lay the scientific hierarchy within a more substantial authority by incorporating the afterlife and God's creation itself as the end of the material layer. In the Islamization of science, Islamic science will choose the sciences that are considered

54 Taufik Mukmin, "Klasifikasi dan Integrasi Pengetahuan dan Aplikasinya dalam Kurikulum”, el-Gbiroh, Vol. 1, No. 1 (February 2011), p. 91.

55 Azyumardi Azra, "Reintegrasi Ilmu-Ilmu dalam Islam”, Zainal Abidin Bagir (ed.), Integrasi Ilmu dan Agama: Interpretasi dan Aksi (Bandung: Mizan, 2005), p. 242.

${ }^{56}$ Kuntowijoyo, Islam Sebagai Ilmu: Epistemologi, Metodologi, dan Etika (Yogyakarta: Tiara Wacana, 2006), p. 55.

57 Yusriyah, "The Reconstruction of Islamic Theology in the Unity of Science", Walisongo, Volume 23, Nomor 2 (2013), p. 378. 
Islamic and discard the non-Islamic (incompatible with Islam). Integration is intended to connect the general and Islamic science without eliminating the uniqueness between the two sciences.

In its history, both religious and general sciences have been independent and have a sound epistemological source. In the view of Amin Abdullah, the integration of science has a weakness. In his view, the nature of integration is merely a smelter and a gap between general Islamic studies that sometimes do not get along together because they want to defeat each other. According to him, it requires a more thoughtful and interconnectional effort. Interconnectivity is an attempt to understand the complexity of the phenomena of life faced and lived by humans that bring to the ideal that any structure of any science, whether religious science (Islam, Christianity, Buddhism, etc.), social science, humanities cannot stand alone. They require cooperation, mutual communication, mutual need, mutual correction and interconnectedness between scientific disciplines. ${ }^{58}$ An integrativeinterconnected approach is an approach that will not melt between the two. It is an approach that seeks mutual respect, conscious of limitations, and solves human problems. It will be cooperation, at least knowing the difficulty of approach and method of thinking between the two kinds of science.

The integrative and interconnected paradigm presupposes the opening of dialogue between the sciences as integrativeinterconnection paradigm is attempt to make a connection in a network between religious science and general science incorporated in the social sciences and the humanities. Establishment of an integrative and interconnected approach is to make the science of the university experiencing the process of objectification. In addition, it also will be beneficial as Non-Muslims will see and receive the result of the science as the science not as a religious act. At the same time, from the Islamic perspective itself, the beneficial act still can be regarded as a religious act that will also be the representation that Islam can be the blessing to all (rạ̣matan li al 'älamin).

Here, Islam experiences objectivity when religious ethics becomes a religious science that is beneficial to humankind as a whole. In the future, science with its moral base is a humanistic religion that ideally being applied in various disciplines and scientific areas range from

58 M. Amin Abdullah, Islamic Studies di Perguruan Tinggi: Pendekatan Integratif dan Interkonektif (Yogyakarta: Pustaka Pelajar, 2006), pp. vii-viii. 
psychology, sociology, anthropology, health, technology, economics, politics, and so on. In relation to this, Students in Pesantren should not only deepen the religious sciences; the also must be equipped with the so called general science such as psychology, sociology, anthropology, health, technology, economics, politics, and so forth.

The working pattern that distinguishes between the interconnected approach and the Islamization of science is by the sorting, fusion, and cluttering between religious and general science. It can be said that the interconnected approach is more humble since it appreciates the actual general science while seeking equality and incorporating Islamic scientific values into it so that general and religious sciences can work together without one defeating the other. This is surely a note worth paying attention to especially by those who are in Islamic educational institutions, especially the Pesantren.

\section{Conclusion}

One biggest factor behind Sukarno's idea for the urgency to integrate religion and science is his concern for declined educational process within Pesantren during the colonialism. Sukarno viewed that Pesantren education at that time was old-fashioned and did not have the spirit of nationalism. In addition, he also viewed that the teaching system separated between religious aspects and general sciences.

To him, there should be no dichotomy between religious science and general (secular) science in Pesantren education because the two sciences have similar orientation and can complement each other. The science of religion is equal to general science in the education system. Sukarno assumed that the advancement of Islam could only be achieved if Muslims can escape from dichotomous restraints and put all science in a balanced and proportional portion. In this case, Sukarno refers to general science in western science. []

\section{References}

\section{Books and Articles}

Abdullah, M. Amin, et al. Islamic Studies dalam Paradigma IntegratifInterkonektif. Yogyakarta: Suka-Press, 2007.

Abdullah, M. Amin. Islamic Studies di Perguruan Tinggi: Pendekatan Integratif dan Interkonektif. Yogyakarta: Pustaka Pelajar, 2006. 
Adams, Cindy. Bung Karno Penyambung Lidah Rakyat Indonesia. Jakarta: Gunung Agung, 1982.

al-Faruqi, Ismail Raji. Islamisasi Ilmu Pengetahuan, trans. A. Mahyuddin. Bandung: Pustaka, 1984.

Anshari, Endang Saifuddin. Wawasan Islam: Pokok-Pokok Pikiran tentang Islam dan Umatnya. Jakarta: Rajawali Press, 1991.

Arif, Mahmud. Pendidikan Islam Transformatif. Yogyakarta: LKiS, 2008.

Azra, Azyumardi. "Reintegrasi Ilmu-Ilmu dalam Islam." Zainal Abidin Bagir (ed.). Integrasi Ilmu dan Agama: Interpretasi dan Aksi. Bandung: Mizan, 2005.

--------. "Rekonstruksi Kritis Ilmu dan Pendidikan Islam." Abdul Munir Mulkhan, et al. Religiusitas Iptek. Yogyakarta: Fakultas Tarbiyah IAIN Sunan Kalijaga Yogyakarta and Pustaka Pelajar, 1998.

Dahm, Benhard. Soekarno dan Perjuangan Kemerdekaan, trans. Hasan Basri. Jakarta: LP3ES, 1987.

Darda, Abu. "Integrasi Ilmu dan Agama: Perkembangan Konseptual di Indonesia." At-Ta'dib, Vol. 10, No. 1, June 2015

Esposito, John L. Kesalahpahaman Barat Terhadap Islam, trans. Sunarto. Yogyakarta: Pustaka Pelajar, 1997.

Falah, Maslahul. Islam ala Soekarno: Jejak Langkah Pemikiran Islam Liberal. Yogyakarta: Kreasi Wacana, 2003.

Geertz, Clifford. Islam yang Saya Amati: Perkembangan di Maroko dan Indonesia. Jakarta: YIIS, 1982.

Gibb, HAR. Aliran-Aliran Modern dalam Islam. Jakarta: Tinta Mas, 1954.

Hoodbhoy, Pervez. Ikhtiar Menegakkan Rasionalitas. Bandung: Mizan, 1996.

Hooker, MB. Islam Mazhab Indonesia: Fatwa-Fatwa dan Perubahan Sosial. Jakarta: Teraju, 2003.

Huntington, Samuel P. Benturan Antara Peradaban dan Masa Depan Politik Dunia, trans. MS. Ismail. Yogyakarta: Qalam, 2000.

Iksanuddin, M. "Dinamika dan Tantangan Pondok Pesantren Masa Kini." Unpublished paper, Department of Sosiologi Agama, Ushuluddin Faculty, UIN Sunan Kalijaga Yogyakarta, 2009. 
Isak, Joesoef (ed.). 100 Tabun Bung Karno. Jakarta: Hasta Mitra, 2001.

Jainuri, Achmad. Ideologi Kaum Reformis: Melacak Pandangan Keagamaan Mubammadiyah Periode Awal. Surabaya: LPAM, 2002.

Jalaluddin and Usman Said. Filsafat Pendidikan Islam. Jakarta: Raja Grafindo Persada, 1990.

Kuntowijoyo. Islam Sebagai Ilmu: Epistemologi, Metodologi, dan Etika. Yogyakarta: Tiara Wacana, 2006.

Kurniawan, Syamsul. "Dikotomi Agama dan Ilmu dalam Sejarah Umat Islam, Serta Kemungkinan Pengintegrasiannya." Fikrah, Vol 1, No 1 (2013).

--------. Gagasan Pendidikan Kebangsaan Soekarno: Ide Progresif Atas Pendidikan Islam Indonesia. Malang: Madani, 2016.

Madjid, Nurchalish. Kaki Langit Peradaban Islam. Jakarta: Paramadina, 1997.

Mortimer, Edward. Islam dan Kebebasan, trans. Ena Hadi. Bandung: Mizan, 1984.

Muhadjir, Noeng. Metodologi Penelitian Kualitatif. Yogyakarta: Rake Sarasin, 1996.

Mukmin, Taufik "Klasifikasi dan Integrasi Pengetahuan dan Aplikasinya dalam Kurikulum." el-Ghiroh, Vol 1, No 1 (2011).

Muliawan, Jasa Ungguh. Pendidikan Islam Integratif. Yogyakarta: Pustaka Pelajar, 2005.

Noer, Deliar. Gerakan Modern Islam Indonesia 1900-1942. Jakarta: LP3ES, 1996.

Noorsena, Bambang. Religi dan Religiusitas Bung Karno: Keberagamaan Mengokohkan Keindonesiaan. Bali: Djagadita Press, 2001.

Razaq, Nasruddin. Dienul Islam. Bandung: Al-Maarif, 1996.

Shihab, Alwi. Membendung Arus: Respons Gerakan Mubammadiyah terhadap Penetrasi Misi Kristen di Indonesia. Bandung: Mizan, 1998.

Soeharto, Pitut and A. Zainoel Ihsan. Aku Pemuda Kemarin d Hari Esok: Kapita Selekta Kumpulan Tulisan Asli, Ląing Pidato Tokoh Pergerakan Kebangsaan 1913-1938. Jakarta: Jaya Sakti, 1981.

Steenbrink, Karel A. Pesantren, Madrasah, dan Sekolah. Jakarta: LP3ES, 1992. 
Sukarno. Dibawah Bendera Revolusi. Jakarta: Panitya Penerbit Dibawah Bendera Revolusi, 1965.

Sukarno. Sarinah. Jakarta: Panitya Penerbit Karangan Presiden Sukarno, 1963.

Sulaiman, Abdul Hamid Abu (ed.). Islamization of Knoledge general Principles and Work Plan. Virginia: USA: IIIT, 1989.

Suryanegara, Ahmad Mansur. Menemukan Sejarab: Wacana Pergerakan Islam di Indonesia. Bandung: Mizan, 1998.

Susilo, Taufik Adi. Soekarno: Biografi Singkat 1901-1970. Yogyakarta: Garasi, 2008.

Tilaar, HAR. Paradigma Baru Pendidikan Nasional. Jakarta: Rineka Cipta, 2000.

Widodo, Sembodo Ardi. "Problematika Pendidikan Islam: Suatu Tinjauan dari Aspek Epistemologi.” Abdurrahman Assegaf, et al. Pendidikan Islam di Indonesia. Yogyakarta: Suka Press, 2007.

Yatim, Badri. Soekarno, Islam dan Nasionalisme. Jakarta: Logos Wacana Ilmu, 1998.

Yusriyah. "The Reconstruction of Islamic Theology in the Unity of Science." Walisongo, Vol 23, No 2 (2013). 
Syamsul Kurniawan

246 JOURNAL OF INDONESIAN ISLAM

VOLUME 12, NuMBER O2, DECEMBER 2018 